\title{
Korelasi Kadar Feritin Serum Terhadap Fungsi Paru pada Pasien Talasemia $\beta$ Mayor
}

Luh Gde Ayu Pramitha Dewi, Ayu Setyorini Mestika Mayangsari, Ida Bagus Subanada, Putu Siadi Purniti, AANKP Widnyana Bagian Ilmu Kesehatan Anak Fakultas Kedokteran Universitas Udayana/RSUP Sanglah, Denpasar

Latar belakang. Talasemia merupakan penyakit anemia hemolitik herediter akibat defek genetik pembentukan rantai globin. Tata laksana talasemia dengan transfusi darah dapat menimbulkan penumpukan besi di berbagai jaringan seperti paru.

Tujuan. Untuk mengetahui korelasi kadar feritin serum terhadap fungsi paru pada anak talasemia $\beta$ mayor.

Metode. Studi analitik potong lintang dilakukan di RSUP Sanglah sejak Juli-Agustus 2017. Subjek diambil secara konsekutif dengan kriteria inklusi semua anak talasemia usia $\geq 6$ tahun, mendapatkan transfusi darah rutin dan kelasi besi. Kriteria eksklusi adalah anak penderita talasemia dengan penyakit paru kronis dan tidak kooperatif saat spirometri.

Hasil. Dari total 31 pasien talasemia di RSUP Sanglah, 28 subjek memenuhi kriteria inklusi dan tidak ada yang memenuhi kriteria eksklusi. Pada penelitian ini median usia pasien talasemia 12,5 tahun dengan kadar rerata feritin serum 3196,5 g/dL. Hasil spirometri dengan median vital capacity (VC) 75\%, force vital capacity (FVC) 82,5\%, force expiratory volume in one second (FEV1) 80,6\%, FEV1/ FVC 101,9\%. Korelasi kadar feritin serum terhadap semua parameter fungsi paru yaitu VC, FVC, FEV1, dan FEV1/FVC adalah sangat lemah dengan masing-masing nilai $r$ adalah $(r=0,016 ; p=0,936),(r=0,181 ; p=0,357),(r=0,305 ; p=0,114),(r=0,158 ; p=0,42)$. Kesimpulan. Korelasi kadar feritin serum terhadap semua parameter fungsi paru didapatkan korelasi lemah dan tidak bermakna secara statistik. Sari Pediatri 2019;21(3):183-8

Kata kunci: talasemia, kelebihan besi, feritin, spirometri, fungsi paru

\section{Correlation of Serum Ferritin Level to Lung Function in Patient with Thalassemia $\beta$ Mayor}

Luh Gde Ayu Pramitha Dewi, Ayu Setyorini Mestika Mayangsari, Ida Bagus Subanada, Putu Siadi Purniti, AANKP Widnyana

Background. Thalassemia is hereditary hemolytic anemia caused by a genetic defect of globin chain formation. Treatment of thalassemia is a blood transfusion, where the result is the iron overload in various tissues such as a lung.

Objective. To know the correlation between ferritin serum and lung function in children with thalassemia $\beta$ mayor

Methods. Cross-sectional analytical studies were conducted at Sanglah Hospital from July to August 2017. Subjects were taken consecutive sampling with inclusion criteria of all children with thalassemia aged $\geq 6$ years who received routine blood transfusion, and iron chelation. Exclusion criteria are children with thalassemia who get chronic lung disease such as asthma, not cooperative to do spirometry

Results. A total 31 thalassemia patients at Sanglah Hospital, only 28 patient enroll in the study. Median age of thalassemia patients was 12.5 years. Serum ferritin levels in thalassemia patients $3196.5 \mathrm{~g} / \mathrm{dL}$, with median vital capacity (VC) spirometry $75 \%$, force vital capacity (FVC) 82.5\%, force expiratory volume in one second (FEV1) 80.6\%, FEV1 / FVC 101.9\%. The correlation of serum ferritin level to all parameter lung function such as VC, FVC, FEV1, and FEV1/FVC was very weak with $r$ value $(r=0,016$; $p=0,936)$, $(\mathrm{r}=0,181 ; \mathrm{p}=0,357),(\mathrm{r}=0,305 ; \mathrm{p}=0,114),(\mathrm{r}=0,158 ; \mathrm{p}=0,42)$ respectively.

Conclusion. The correlation of serum ferritin level to all spirometry parameter was obtained with a weak correlation and not statistically significant. Sari Pediatri 2019;21(3):183-8

Keywords: thalassemia, iron overload, ferritin, spirometry, lung function

Alamat korespondensi: Luh Gde Ayu Pramitha Dewi. Bagian Ilmu Kesehatan Anak Fakultas Kedokteran Universitas Udayana/RSUP Sanglah, Denpasar. Email: ayupramithadewi@gmail.com 
Luh Gde Ayu Pramitha Dewi dkk: Korelasi kadar feritin serum terhadap fungsi paru pada pasien talasemia $\beta$ mayor

$\mathrm{T}$ alasemia merupakan penyakit anemia hemolitik herediter yang disebabkan oleh defek genetik dari pembentukan rantai globin. ${ }^{1}$ Pada pasien talasemia terjadi sintesis hemoglobin yang tidak normal sehingga terjadi penurunan pengantaran oksigen ke jaringan, eritropoiesis tidak efektif, dan kelebihan besi. Mekanisme paru yang tidak normal disebabkan oleh konsentrasi hemoglobin yang rendah sehingga mengakibatkan penurunan kapasitas difusi paru. ${ }^{2}$

Sampai saat ini tata laksana talasemia masih dengan transfusi darah berkala. Saat transfusi darah, setiap unit atau satuan sel darah merah yang akan ditransfusikan mengandung $200 \mathrm{mg}$ besi sehingga akumulasi besi masih menjadi permasalahan sampai saat ini. Pada pasien dengan talasemia $\beta$ mayor, kecepatan transfusi dan akumulasi besi pada saluran cerna mencapai 0,3-0,6 $\mathrm{mg} / \mathrm{kg} /$ hari. Peningkatan absorpsi besi menyebabkan anemia berat dan eritropoiesis yang tidak efektif sehingga terjadi penimbunan besi di berbagai organ. ${ }^{3,4}$ Untuk meningkatkan kapasitas pengantaran oksigen, pasien talasemia akan mendapatkan transfusi darah secara berkala sehingga menimbulkan penumpukan besi pada jantung, hati, kelenjar endokrin, dan paru. Pada pemeriksaan postmortem, pasien yang mendapatkan transfusi darah berulang didapatkan deposisi besi pada paru yang dapat mengakibatkan kerusakan parenkim paru. ${ }^{5,6,7}$ Untuk mengatasi penimbunan besi yang berlebihan di berbagai organ maka digunakan kelasi besi. Kelasi besi terdiri dari 3 kelas utama, yaitu hexadentate (deferoxamine/DFO, Desferal) 1 atom besi mengikat 1 molekul DFO; bidentate (deferiprone, L1 (DFP)) 1 atom besi mengikat 3 molekul DFP; dan tridentate (deferasirox/DFX, Exjade) 1 atom besi mengikat 2 molekul DFX.,3 Sampai saat ini, hubungan antara gangguan fungsi paru yang tergantung transfusi dan kelebihan besi pada pasien talasemia belum jelas diketahui. ${ }^{5,6}$

Pemeriksaan yang dapat digunakan untuk menggambarkan fungsi paru adalah dengan spirometri. Pada spirometri dapat dievaluasi beberapa parameter fungsi paru, seperti vital capacity (VC), forced vital capacity (FVC), dan forced expiratory volume in one second (FEV1). ${ }^{8,9}$

Tujuan dari penelitian ini adalah untuk mengetahui korelasi kadar feritin serum terhadap fungsi paru pada anak dengan talasemia $\beta$ mayor. Hasil penelitian ini diharapkan dapat dipakai untuk memberikan pengetahuan tambahan bagi orangtua, dokter, atau paramedis tentang bahaya deposisi besi yang berlebihan di jaringan tubuh.

\section{Metode}

Penelitian ini menggunakan desain analitik potong lintang yang dilakukan di RSUP Sanglah sejak bulan Juli hingga Agustus 2017. Subjek penelitian diambil secara konsekutif dengan kriteria inklusi adalah semua anak-anak penderita talasemia usia $\geq 6$ tahun -18 tahun yang telah mendapatkan transfusi darah secara rutin setiap bulan (minimal 10 kali transfusi) dan mengkonsumsi kelasi besi (Deferasirox ${ }^{\oplus} 20-40 \mathrm{mg} /$ $\mathrm{kgbb} / \mathrm{hari}$ oral tiap 24 jam atau Deferiprone $75 \mathrm{mg} /$ $\mathrm{kgbb} / \mathrm{hari}$ oal tiap 8 jam). ${ }^{10}$ Kriteria eksklusi adalah anak-anak talasemia dengan penyakit paru kronis seperti asma, serta tidak kooperatif saat melakukan tindakan spirometri. Penelitian ini menggunakan kesalahan tipe $15 \%$, kekuatan 90\%, dengan koefisien korelasi yang dianggap bermakna 0,49 , sehingga diperoleh besar sampel minimal 32 orang.

Talasemia didefinisikan sebagai penyakit anemia hemolitik herediter yang diagnosis oleh dokter berdasarkan pemeriksaan high performance liquid chromatography (HPLC), dan rutin mendapatkan transfusi darah. Ferritin serum adalah protein yang mengandung zat besi yang diperiksa di laboratorium RSUP Sanglah Denpasar dengan satuan nanogram/ mililiter (ng/mL). Untuk pemeriksaan ferritin, darah vena diambil sebanyak $3 \mathrm{ml}$, diperiksa dengan teknik immunoassay menggunakan alat kimia analyzer Cobas C051. Nilai normal ferritin adalah 6-67 ng/mL. Hepatomegali adalah pembesaran hepar yang diperiksa dengan palpasi bimanual dan didapatkan pembesaran $4 \mathrm{~cm}$ di bawah arcus costa dan prosesus xypoideus. Splenomegali merupakan pembesaran lien yang diperiksa dengan palpasi bimanual dan didapatkan pembesaran yaitu pembesaran lien yang melewati garis khayal dari mid clavicula line kiri hingga umbilicus. ${ }^{11}$

Nilai spirometri dibagi menjadi 3, yaitu normal (bila ditemukan $\mathrm{FVC} \geq 80 \%$, FEV1 $\geq 80 \%$, dan ratio FEV1/FVC $>70 \%$ ), restriktif (bila ditemukan FVC $<80 \%, \mathrm{FEV} 1>80 \%$ atau $<80 \%$, dan ratio $\mathrm{FEV} 1 /$ FVC $>70 \%$ ), dan obstruksi (bila ditemukan FVC $\geq 80 \%$, FEV1 $<80 \%$ dan ratio FEV1/FVC $<70 \%) .{ }^{12}$ Pemeriksaan spirometri dilakukan oleh peneliti serta ditemani oleh pembimbing.

Penelitian ini telah mendapatkan persetujuan 
Komisi Etik Penelitian Fakultas Kedokteran Universitas Udayana dengan nomor kelaikan etik: 1893/UN.14.2/ $\mathrm{KEP} / 2017$. Seluruh data dianalisis menggunakan Statistical Package for the Social Sciences (SPSS) dan analisis data korelasi menggunakan uji Spearman karena distribusi data tidak normal berdasarkan uji Shapiro-Wilk.

\section{Hasil}

Selama periode penelitian, didapatkan 31 jumlah subjek pasien talasemia $\beta$ mayor di RSUP Sanglah. Tiga orang berusia $<6$ tahun sehingga besar sampel yang diteliti adalah 28 subjek. Median usia pasien talasemia di RSUP Sanglah adalah 12,5 tahun dengan rentang usia 6 hingga 18 tahun. Proporsi pasien yang melakukan transfusi darah setiap 4 minggu sebesar $89,3 \%$. Ukuran hepar lebih banyak didapatkan tidak teraba, yaitu $22(78,6 \%)$ kasus, pembesaran hati kurang dari $3 \mathrm{~cm} 5(17,9 \%)$ dan lebih dari $3 \mathrm{~cm}$ hanya pada $1(3,6 \%)$ kasus. Pada penelitian ini pembesaran lien yang dialami subjek lebih banyak kurang dari schuffner II, yaitu pada 19 kasus $(67,9 \%)$. Semua subjek menggunakan kelasi besi secara rutin dengan tipe kelasi besi lebih banyak deferasirox (Exjade) yaitu $23(82,1 \%)$ dan sisanya deferiprone (Ferriprox $\left.{ }^{\circ}\right)$ yaitu $5(17,9 \%)$ kasus. Dari 28 subjek yang dilakukan pemeriksaan spirometri didapatkan 13 (46,4\%) memiliki fungsi paru normal, $13(46,4 \%)$ restriktif, dan $2(7,1 \%)$ kasus obstruktif (Tabel 1).

Rerata kadar serum feritin pada pasien talasemia $\beta$ mayor 3196,5 ng/mL. Rentang nilai rujukan serum feritin adalah $13-68 \mathrm{ng} / \mathrm{mL}$ dan tidak ada subjek

Tabel 1. Karakteristik subjek penelitian

\begin{tabular}{|c|c|}
\hline Variabel & Subjek $n=28$ \\
\hline Umur, median, IQR, th & $12,5(6-18)$ \\
\hline \multicolumn{2}{|l|}{ Jenis kelamin, $\mathrm{n}(\%)$} \\
\hline Lelaki & $12(42,9)$ \\
\hline Perempuan & $16(57,1)$ \\
\hline \multicolumn{2}{|l|}{ Frekuensi transfusi, n (\%) } \\
\hline Tiap 2 minggu & $1(3,6)$ \\
\hline Tiap 3 minggu & $2(7,1)$ \\
\hline Tiap 4 minggu & $25(89,3)$ \\
\hline \multicolumn{2}{|l|}{ Volume transfusi, n (\%) } \\
\hline$<10.000 \mathrm{ml}$ & $5(17,9)$ \\
\hline$>10.000 \mathrm{ml}$ & $23(82,1)$ \\
\hline \multicolumn{2}{|l|}{ Hepatomegali, n (\%) } \\
\hline Tidak teraba & $22(78,6)$ \\
\hline$<3 \mathrm{~cm}$ & $5(17,9)$ \\
\hline$\geq 3 \mathrm{~cm}$ & $1(3,6)$ \\
\hline \multicolumn{2}{|l|}{ Splenomegali, n (\%) } \\
\hline Tidak teraba & $2(7,1)$ \\
\hline$<$ SII & $19(67,9)$ \\
\hline$\geq$ SII & $7(25)$ \\
\hline \multicolumn{2}{|l|}{ Konsumsi kelasi besi, n (\%) } \\
\hline Rutin & $28(100)$ \\
\hline \multicolumn{2}{|l|}{ Jenis kelasi besi, n (\%) } \\
\hline Deferasirox (Exjade $\left.{ }^{\circ}\right)$ & $23(82,1)$ \\
\hline Deferiprone (Ferriprox $\left.{ }^{\circ}\right)$ & $5(17,9)$ \\
\hline \multicolumn{2}{|l|}{ Spirometri, n (\%) } \\
\hline Normal $(\mathrm{FVC} \geq 80 \%, \mathrm{FEV} 1 \geq 80 \%$, dan ratio FEV1/FVC >70\%) & $13(46,4)$ \\
\hline Restriktif (FVC $<80 \%$, FEV1 $>80 \%$ atau $<80 \%$, dan ratio FEV1/FVC $>70 \%$ ) & $13(46,4)$ \\
\hline Obstruksi (FVC $\geq 80 \%$, FEV1 $<80 \%$ dan ratio FEV1/FVC $<70 \%)$ & $2(7,1)$ \\
\hline
\end{tabular}

IQR: interquartile range 
Tabel 2. Gambaran kadar feritin dan hasil spirometri

\begin{tabular}{lc}
\hline Variabel & Subjek $\mathrm{n}=28$ \\
\hline Kadar feritin serum, rerata, (SB), g/dL & $3196,5(2733)$ \\
VC, median, IQR, \% & $75(47,5-112,3)$ \\
FVC, median, IQR, \% & $82,5(49,6-109,9)$ \\
FEV1, median, IQR, \% & $80,6(55,9-107,9)$ \\
FEV1/FVC, median, IQR, \% & $101,9(76,7-111,4)$ \\
\hline
\end{tabular}

IQR: interquartile range, SB: simpang baku

Tabel 3. Hasil analisis korelasi kadar feritin serum dengan VC, FVC, FEV1, FEV1/FVC

\begin{tabular}{lcc}
\hline Variabel & $\mathrm{r}$ & Nilai p \\
\hline Kadar feritin serum terhadap VC & 0,016 & 0,936 \\
Kadar feritin serum terhadap FVC & 0,181 & 0,357 \\
Kadar feritin serum terhadap FEV1 & 0,305 & 0,114 \\
Kadar feritin serum terhadap FEV1/FVC & 0,158 & 0,420 \\
\hline
\end{tabular}

Tabel 4. Hasil analisis korelasi kadar feritin serum dengan VC, FVC, FEV1, FEV1/FVC pada anak talasemia tanpa organomegali

\begin{tabular}{lcc}
\hline Variabel & $\mathrm{r}$ & Nilai p \\
\hline Kadar feritin serum terhadap VC & $-0,137$ & 0,553 \\
Kadar feritin serum terhadap FVC & 0,070 & 0,763 \\
Kadar feritin serum terhadap FEV1 & 0,342 & 0,130 \\
Kadar feritin serum terhadap FEV1/FVC & 0,294 & 0,196 \\
\hline
\end{tabular}

yang memiliki kadar serum feritin yang normal. Hasil pemeriksaan spirometri pada pasien talasemia $\beta$ mayor didapatkan median VC 75\% (47,5-112,3\%), FVC $82,5 \%$ (49,6-109,9\%), FEV1 80,6\% (55,9-107,9\%), FEV1/FVC 101,9\% (76,7-111,4\%) (Tabel 2).

Korelasi kadar feritin serum terhadap hasil spirometri tertera pada Tabel 3. Hasil korelasi kadar feritin serum terhadap semua parameter fungsi paru yaitu VC, FVC, FEV1, dan FEV1/FVC adalah sangat lemah dengan masing-masing nilai $\mathrm{r}$ adalah $(\mathrm{r}=0,016$; $\mathrm{p}=0,936),(\mathrm{r}=0,181 ; \mathrm{p}=0,357),(\mathrm{r}=0,305 ; \mathrm{p}=0,114)$, $(\mathrm{r}=0,158 ; \mathrm{p}=0,42)$. Korelasi tetap lemah walau sudah dilakukan usaha mengeluarkan subjek dengan faktor pembesaran organ bermakna yaitu hepatomegali lebih dari $3 \mathrm{~cm}$ dan splenomegali lebih dari Schuffner II (Tabel 4).

\section{Pembahasan}

Talasemia $\beta$ mayor adalah grup anemia hipokromik dengan berbagai derajat keparahan, penyakit talasemia ini diturunkan secara genetik. Defek genetik yang mendasari penyakit ini adalah delesi total atau parsial rantai globin dan substitusi, delesi atau insersi nukleotida. Konsekuensi perubahan ini berupa penurunan atau hilangnya mRNA untuk satu atau lebih rantai goblin atau tidak efektifnya pembentukan mRNA. ${ }^{13}$ Gangguan fungsi paru pada pasien talasemia $\beta$ mayor telah diketahui dalam tiga dekade terakhir meskipun sampai saat ini mekanisme patogenesisnya belum sepenuhnya diketahui. Berbagai variasi gangguan fungsi paru ditemukan pada pasien talasemia $\beta$ mayor berupa gangguan fungsi paru restriktif, obstruktif, dan atau campuran. ${ }^{11}$

Median usia pasien talasemia di RSUP Sanglah 12,5 tahun, lebih banyak berjenis kelamin perempuan $16(57,1 \%)$. Temuan ini serupa dengan laporan penelitian Sani dkk. ${ }^{11}$ Sementara Aurora $\mathrm{dkk}^{4}$ melaporkan rerata usia pasien talasemia $\beta$ mayor $11,83 \pm 1,91$ tahun (rentang usia 9-17 tahun) dengan rasio laki-laki dibandingkan dengan perempuan 1:1.

Pada penelitian yang dilakukan Said dkk, ${ }^{14}$ transfusi darah PRC 15-20 ml/kgBB biasanya 
diberikan setiap 4-5 minggu. Transfusi darah $500 \mathrm{ml}$ dapat mengantarkan $200 \mathrm{mg}$ besi kedalam jaringan karena tidak bisa diekskresikan secara fisiologis oleh tubuh. Transfusi darah berulang dapat menyebabkan deposisi besi pada paru sehingga menyebabkan kerusakan parenkim paru. ${ }^{7}$ Kerusakan pada parenkim paru menyebabkan aliran udara terganggu sehingga pada pemeriksaan spirometri didapatkan pada sebagian kasus mengalami gangguan paru restriktif. Organomegali seperti hepatomegali dan splenomegali dapat menghambat pergerakan diafragma yang mengakibatkan gangguan volume dan kapasitas paru. Penelitian yang dilakukan oleh Sani $\mathrm{dkk}^{11}$ diperoleh tidak terdapat hubungan antara hepatomegali dan splenomegali dengan gangguan fungsi paru.

Kelasi besi digunakan untuk membantu mengurangi kelebihan besi di dalam tubuh sehingga besi bisa diekskresikan lewat urin dan feses. Secara umum, kelasi besi mulai diberikan setelah pasien menjalani transfusi darah 2-3 tahun atau ketika kadar feritin serum melebihi 1000 ng/ml. Adapun efek samping yang dapat ditimbulkan dari penggunaan kelasi besi, antara lain tuli, kerusakan retina hingga menyebabkan gangguan penglihatan, gangguan pertumbuhan, kerusakan tulang, gangguan pencernaan, defisiensi seng, dan peningkatan fungsi hati. Sampai saat ini tidak didapatkan efek samping penggunaan kelasi besi pada organ paru. ${ }^{15,16}$ Pada penelitian ini semua subjek menggunakan kelasi besi secara rutin terutama dengan deferasirox (Exjade) dan sisanya menggunakan deferiprone (Ferriprox'). Pemberian kelasi besi telah rutin diberikan pada pasien talasemia yang memiliki kadar feritin serum $>1000 \mathrm{ng} / \mathrm{ml}$, dan sebagian besar kasus tidak mengalami organomegali bermakna. Pemakaian kelasi besi serta organomegali yang tidak begitu besar menyebabkan pergerakan diafragma masih dalam batas normal sehingga ada sebagian subjek yang masih memiliki fungsi paru normal.

Said $\mathrm{dkk}^{14}$ melaporkan bahwa FVC dan FEV1 pada pasien talasemia lebih rendah dibandingkan nilai prediktif $(<80 \%)$, tetapi FEV1/FVC dan peak exspiratory flow (PEF) dalam batas normal. Sementara Sani $\mathrm{dkk}^{10}$ melaporkan berdasarkan analisis ROC, kadar feritin serum $4839 \mu \mathrm{g} / \mathrm{L}$ merupakan batasan kadar feritin serum yang mengarah pada gangguan fungsi paru. Pada penelitian ini gangguan fungsi paru yang sering terjadi pada pasien talasemia $\beta$ mayor adalah gangguan paru restriktif, yaitu $13(46,4 \%)$ subjek. Hal tersebut sesuai dengan penelitian yang dilakukan oleh Said $\mathrm{dkk}^{14}$ bahwa gangguan paru tersering pada pasien talasemia adalah gangguan tipe restriktif 42/63 subjek.

Korelasi kadar feritin serum terhadap semua parameter fungsi paru tidak bermakna, bahkan setelah faktor perancu seperti organomegali dihilangkan. Hasil penelitian ini sama dengan penelitian yang dilakukan oleh Said dkk ${ }^{14}$ dan Carnelli dkk. ${ }^{7}$ Pada penelitian tersebut didapatkan FVC tidak berhubungan dengan kadar serum ferritin, baik pada pasien talasemia lelaki dan perempuan. Disamping itu, korelasi antara fungsi paru dan kadar serum ferritin juga tidak ditemukan meskipun kelebihan besi masih berperan dalam mekanisme abnormalitas paru. Feritin serum merupakan reaktan fase akut yang dipengaruhi oleh berbagai faktor, seperti penyakit inflamasi, penyakit hati, dan keganasan. Feritin serum bukan pemeriksaan yang terbaik untuk menandai suatu kelebihan besi di paru. Standar baku emas yang dapat digunakan untuk mengetahui adanya kelebihan besi di organ paru berupa biopsi paru, tetapi tindakan tersebut sangat invasif. ${ }^{10,17}$

Penelitian yang dilakukan oleh Said $\mathrm{dkk}^{14}$ mengatakan kadar feritin serum berkorelasi positif dengan usia, tetapi tidak berkorelasi dengan variabel spirometri. Dikatakan bahwa durasi kelebihan besi lebih berperan daripada jumlah aktual besi yang didapatkan dari transfusi darah. Kadar feritin serum akan berubah selama proses kelasi sehingga tidak dapat mencerminkan penyimpanan total besi di dalam tubuh. Penelitian ini hanya menampilkan data kadar feritin serum yang terakhir sehingga kurang mampu mencerminkan hubungan antara gangguan fungsi paru dan kelebihan besi. Semua subjek menggunakan kelasi besi secara rutin sehingga banyak besi bebas terikat yang membuat fungsi paru sebagian subjek masih dalam batas normal.

Kelemahan studi ini adalah tidak membandingkan hasil pemeriksaan fungsi paru pada anak yang normal, tidak menggunakan biopsi paru sebagai standar emas pemeriksaan kelebihan besi di jaringan, serta jumlah sampel tidak sesuai dengan besaran sampel.

\section{Kesimpulan}

Terdapat korelasi yang lemah serta tidak bermakna secara statistik antara kadar feritin serum terhadap fungsi paru pada pasien talasemia $\beta$ mayor. 


\section{Daftar pustaka}

1. Ekteish FA, Rimawi HA, Ali MA, Shehabi IM. Pulmonary function test in children with beta-talasemia major. Chron Respir Dis 2007;4:19-22.

2. Tai DY, Wang YT, Lou J, Wang WY, Mak KH, Cheng HK. Lungs in talasemia major patiens receving regular transfusion. Eur Respir J 1996;9:1389-94.

3. Rachmilewitz EA, Patricia JG. How I treat thalassemia. Blood 2011;118;3479-88.

4. Arora M, Chandra J, Suri JC, Narayana S, Dutta AK. Pulmonary function tests in beta talasemia. Indian J Pediatr 2001;68:239-42.

5. Sohn EY, Noetzli LJ, Gera A, Kato R, Coates TD, Harmatz P, $\mathrm{dkk}$. Pulmonary function in talasemia major and its correlation with body iron store. Br J Haematol 2011;155:102-5.

6. Burgel PR, Bergeron A, Blic J, Bonniaud P, Bourdin A, Chanez P, dkk. Small airways disease, excluding asthma and COPD: an overview. Eur Respir Rev 2013;22:131-47.

7. Carnelli V, D’Angelo E, Pecchiari M, Ligorio M, D’Angelo E. Pulmonary Dysfunction in transfusion-dependent patients with talasemia major. Am J Respir Crit Care Med 2003;168:180-4.

8. Li AM, Chan D, Li CK, Wong E, Chan YL, Fok TF. Respiratory function in patients with talasemia major: relation with iron overload. Arch Dis Child 2002;87:328-30.
9. Dahlan MS. Menghitung Besar Sampel: "Menggunakan Rumus Besar Sampel Secara Benar”. Dalam: Dahlan MS, penyunting. Besar Sampel Dan Cara Pengambilan Sampel. Jakarta: Penerbit Salemba Medika;2013. h. 76.

10. Galanello R, Raffaella O. Beta-thalassemia. Orphanet J Rare Dis 2010;5:1-15

11. Sani MR, Kartasasmita CB, Reniarti L. Hubungan kadar feritin serum dengan gangguan fungsi paru pasien thalassemia mayor anak. Sari Pediatri 2014;16:210-4.

12. Uyainah A, Zulkifli A, Feisal T. Spirometri. Ina J Chest Crit and Emerg Med 2014:1;35-38.

13. Boddu A, A Kumble, S Mahalingam, BS Baliga, B Achappa. Pulmonary dysfunction in children with beta thalassemia major in relation with iron overload-a cross sectional hospital based study.AJMS 2015;6:47-50.

14. Said M, Sudigdo S, Djajadiman G, Bambang S, Yovita A. Comparison of pulmonary functions of thalassemic and of healthy children. Paediatrica Indonesiana 2005;45:1-6.

15. Beutler E, A Victor H, James DC. Iron deficiency and overload. Hematol 2003:40-61.

16. Poggiali E, Elena C, Laura Z, Maria DC. An update on iron chelation therapy. Blood Transfus 2012;10:411-22.

17. Bourli E, Meropi D, Marina E, Efthimia V, Athanasios C, Eleni M, dkk. Restrictive pulmonary dysfunction and its predictors in young patients with b-thalassaemia major. Pediatr Pulmonol 2012;47:1-7. 